\title{
NEGOTIATED URBAN SPACE AT MANGGARAI STATION JAKARTA: THE APPROPRIATION OF SPACE BY BAJAJ DRIVERS
}

\author{
Yulia Nurliani Lukito ${ }^{1 *}$, Rumishatul Ulya ${ }^{2}$ \\ ${ }^{1,2}$ Department of Architecture, Faculty of Engineering Universitas Indonesia, UI Campus, \\ Depok 16424, INDONESIA \\ *Corresponding author; Email: yulianurliani@yahoo.com
}

\begin{abstract}
This paper aims to investigate the negotiation between the "formal" and the "informal" urban space in Jakarta through the examination of use of space of marginalized transportation of bajaj - a three-wheeled public transportation. Bajaj drivers continuously and creatively create their use of space and territory as the result of the limitation of space. Creativity in using space emerges as a way to get available space and this activity results in the appropriation of urban space. The basis of such appropriation is how to survive in urban space and such condition is characterized by negotiation, flexibility and adaptability. In high-density Jakarta city, it is necessary for bajaj drivers - who have only limited possibility in using strategic urban space - to use both the formal and the informal to sustain the city at large. An analysis of how bajaj drivers negotiated urban spaces around Manggarai Station reveals the appropriation of urban space that relies on temporality, tactics and negotiation of rules of access among users. In this paper, we analyze how urban informality as an 'organizing logic' results in a specific mode of the production of space. The analysis of negotiations of space around Manggarai Station is intended to contribute to an understanding of how informal and negotiated spaces, which shape everyday life in the city, are inseparable parts of formal and designed spaces in the city of Jakarta.
\end{abstract}

Keywords: Negotiated space; urban informality; urban space; manggarai station; bajaj.

\section{INTRODUCTION}

Jakarta as the biggest city in Indonesia faces some problems related to social and spatial effect of integrated transportation systems and informal activities. Informal spaces and activities in the city may be seen as excess of urban planners' design of the city. However, informality in the city may actually play an important role in the development of the city but their existence is often seen as out of place. The current methods of reading, interpreting and designing the city represent mostly the formal instruments of the discipline that can be traced back to a functionalist paradigm based on the idea of a centralized, hierarchical control of the city. In real life, a series of parameters and standards alone are incapable of translating urban complexity and understanding informal and temporal activities happen in the city.

Planners and governments may only have few attentions to informal activities in planning the city because informality is often related to phenomena that take place outside formal processes (Roy 2004). Various situations may be included in informality such as spontaneous processes of occupation of the territory, temporary uses of space, and some forms of self-organization of urban areas. As consequences, informal activities in the city are often considered unwanted and inappropriate. Current tendencies of the city, which is outlined towards less formal and more flexible spatial order, prefers a strategic method towards an approach of the tactical type (De Certeau, 1984). Social-dynamics happen in urban spaces and among various actors in the city can be understood by city's structures and elements of interaction that creates many events in urban life with unique characteristic so that those events can be positive (Kudva, 2009). The traditional forms of the city, understood as a permanent and static urban area, is changed into temporary and continuous movement or the "kinetic" urban area (Mehrotra, 2008). The idea of kinetic urban area may be understood as an entity made up of informal activities that may include the multiple uses of urban condition and changing spatial forms such as informal space that is created over time. The phenomena of informality have become a significant part in urban areas and in the production of spaces in the city (Lefebvre, 1991). Recently, some research even has been done to analyze the alternative methods of sharing city spaces.

In designing urban spaces including developing a transportation system, there is sometimes a lack of connection between formal and informal activities and this condition results in an opportunity for some subjects of the city to claim particular space to support their activities. As an example is the phenomena of bajaj drivers that take over public spaces near train 
stations in Jakarta. Bajaj, a three-wheeled taxi, is one of public transportation commonly found in Jakarta and usually used by people who want to travel short distances to places where no buses or minibuses reach. The drivers usually wait for costumers at a strategic part of the city streets as well as occupying sidewalks that have strong invitation elements for people to come. The area used by bajaj drivers to wait for customers are known as pangakalan, which is usually located near markets and commercial areas. This kind of activity of waiting for passengers is called ngetem, but unfortunately, ngetem is often seen as an inappropriate activity for creating some problems like traffic jam and disorder in the city. Ngetem is also considered as an inappropriate action since those drivers do not follow the function of urban space. Bajaj drivers try to occupy strategic areas because they have few designed spaces for their activities in comparison to buses or trains.

In this study, we consider the city structure as both planned and unplanned and people in the city, such as bajaj drivers, use strategy and tactic in occupying the city. The idea of everyday spaces can help us to re-establish the neglected connection between the structure of the city and everyday urban conditions including how people borrowing or changing the function of space. A close observation of the city and people highlights appropriation of space as well as spontaneous utilization of space together with the formal and designated functions. Formal public places such as squares, markets, and parks have often been studied in connection to ideal places but informal activities in everyday places actually create multiple forms of public and result in negotiated spaces. In this way, considering the temporal and informal is extending the borders of meanings in the city. The idea of strategy and tactic in bajaj 'ngetem' can help us to understand the everyday life of the city, and how informal urban spaces are as important as formal and structured spaces. Moreover, considering informality in designing urban space can help to understand the appropriation in the city that is characterized by negotiation and flexibility and adaptability rather than ignoring the existence of it.

\section{URBAN INFORMALITY AND NEGOTIATED SPACE}

Urban space and architecture in a city are strongly connected to people's activities, including how people use formal and informal urban spaces in their everyday life. Formal spaces are related to designed and planned spaces in the cities such as streets and buildings where people do their activities according to the designated functions of the space done by planners. Since people in the city have a capacity to establish a relationship between territory, space and practices, the existence of unplanned and informal spaces cannot be avoided. Informal space may become a disturbing part of the city, regardless the importance of the space to support the activities of people in the cities. Informal space takes shape over time occupying different areas with its borders may enlarge to incorporate the multiple uses of the contemporary urban condition. Informal space also introduces a sense of place with dynamism and temporariness as the basic elements upon which this spatial concept becomes structured (Mehrotra, 2008). The complexity of urban area is then can be analyzed as the relation between economic, spatial form as well as social and cultural processes, including activities that happen both in formal and informal spaces.

There are two important actors in relation to urban space, namely planners and users. Discussing different points of views of those actors will lead us to a better understanding of how people use urban space in everyday life and show that both formal city structure and urban informality are significant. In reality, planners do not have capability to control the consequences of their design and the acts of planners usually represent the broader system of power that do not inevitably respond to the everyday activities. However, urban informality creates a specific mode of the production of space, and thus, it continuously changes the product of planners and the meaning of space as the result of space claiming.

In dealing with city structure, Lynch (1960) suggests five basic physical elements in order to create an image of the city: paths, edges, nodes, districts, and landmarks. In addition to this, Peraboni (2010) offers some other basic elements to understand the structure and the informality of built environment through nodes, corridors and connections, stepping stones, and barriers in order to understand the process of urban space transformation. Nodes are areas that have a high value in relation with its context, which have been identified as key elements to potentiate, and as part of a strategy to consolidate and develop values. Corridors and connections can be understood as a strip of the territory. Stepping stones or an area conceptually attached to the corridors consist of places that act as rest areas for determinate user. Barriers may be understood as things that interrupt the networks. Peraboni (2010) emphasizes that the infrastructure of the city, including what Lynch (1960) describes as landmarks, path, edges, or districts, are strongly connected and should be seen as a mosaic of urban life. Elements of the city, even 
those usually seen as leftover space and considered bad for the city image, are actually a part of the mosaics of urban life.

A discussion of basic elements of the city is related to the space production in everyday life and how users perceive opportunities in certain urban spaces. Lefebvre (1991) discusses the idea of space as a social (re) production that the cities should be seen as a product of the people living their everyday life and people are actually subjects in the production of space who have an important role in constructing space. Therefore, it becomes a necessary thing to examine strategies, tactics and elements in understanding urban informality of the city. As part of the production of space, physical conditions of urban area encourage people's self-organization and creativity in a variety of forms, such as new public spaces and claiming unused space.

Michel de Carteau (1984) in Practice of Everyday Life describes two ways to understand the city. The first one is a totalizing and representational view done by planners who sometimes ignore users in the city from their environment in order to achieve objectivity. De Certeau (1984) illustrates the planner's perspective like a person who stands at the top of a building where one can abandon the everyday realities of living in a city and make the city available for analysis. Seeing the city from above only gives a frozen image of people living in the city but neglect personal experience. The second way to understand the city is through the observation of everyday life in which we can get a more realistic representation of the city we walk in. In this "tactics" way, we can obtain detail images of the city, although those images are not a perfect representation. What matters is not the proper representations but the quality and the significant image of the city and personal experience in making useful correspondences between our conceptual thoughts and experiences.

De Certeau (1984) also examines how people individualize things to suit their needs by using the idea of strategy and tactic. Strategy means any method or rule of power manipulation related to proper places while tactic is a manipulation of activity doing by users that take advantages of "opportunity" in strategic areas. De Certeau (1984) argues that personal and tactic experience is as significant as the totalizing view of the city since the meaning of place may belong to many possible practices. Strategy is usually related to the way planners and government create the structure of the city while tactic is related to space making of people with less power. Personal and tactic approaches do not necessarily conclude what is proper for the city instead tactic is as an adaptation to the urban environment without ending up with defining the practices of those in their proper places and conception, with time subservient to place. It means that tactics are action in a constant state of reassessment, based directly on observations of the actual environment. Therefore, strategies and tactics are two components in everyday architecture and urban life that complement each other.

Everyday life in the city includes a collection of leftover activities and people have their own experiences that give various meanings to urban space (Upton, 2002). This means that some activities in the city are formal or happened according to the plan or in desired places while some activities are informal and happened in leftover spaces or out of plan. Informal space may resemble the idea of negotiated space as a temporal condition that has a continuous existence in urban spaces (Hackenbroch, 2011). In everyday life, there are some claim-making of those informal spaces - which usually happens in public spaces - as a tactic for occupying leftover urban space. Claiming informal spaces occurs in social and political urban life as an inseparable part of city lives (Schneekloth, 1995).

In connecting everyday life and urban design, Margaret Crawford (1999) in Everyday Urbanism mentions the connection between the two is established through an everyday space such as a space that is constructed spontaneously between defined and undefined realms of private, workplace and public spaces. She recognizes three significations in the city: counter practices or looking beyond officially designed practices, re-familiarization or recreating domestic interiors, and borrowing spaces by appropriating the function of space. The temporal and informal are as significant as the formal things in the city and in this way we can accommodate temporality and recognize the importance of human experience and the value of spontaneity.

\section{METHODOLOGY}

This paper discusses informality and negotiated spaces in the city and their relation to physical elements that gives a basis for an explanation of claiming and negotiating spaces. As a case study is pangkalan bajaj around Manggarai Station, East Jakarta, where bajaj drivers parked their vehicle and wait for passengers. The area was a busy urban area, where many people got in and off their vehicles or walked and used trains. Manggarai Station is not only an important transportation hub but also a transit location for people who want to change directions. This study is a descriptive and qualitative analysis of 
the phenomena of bajaj 'ngetem' by examining urban elements that are related to informality and space negotiation in the city done by bajaj drivers. Common issues in transport research were also observed, such as origin and destination, trip purpose and driver's strategy in finding passengers. This study also used a comprehensive literature study on discussing the conditions in Jakarta and informality happened in the city, as well as previous research findings concerning changes in urban space.

The data were obtained through the observation of the physical environment of the Manggarai Station, including the function of the station building and its related physical elements. The observation on the field was meant to identify both physical and nonphysical elements contributed in the creation of negotiated space at Manggarai Station. We observed and analyzed physical elements such as buildings, paths and landmarks as well as activities that were connected to bajaj drivers at Manggarai Station. The observation was complemented by interviews with the people who traveled with trains in order to reveal the spatial issues and spatial strategies practiced by the occupants. The analysis was conducted by identifying important design elements such as paths, entrances, connections and other physical conditions. Based on the general spatial organization in the station and by examining the strategies of strategy of occupying leftover space, we try to identify the everyday spatial strategies of bajaj drivers. The emergence of strategies in relation to the spatial organization of bajaj driver activities becomes the focus of the study.

\section{RESULTS AND DISCUSSION}

Bajaj drivers provide urban services and alternative route to people to reach their destination, especially for middle and lower class. Bajaj is a small three-wheel vehicle that can carry up to three passengers and bring those passengers through alleys where buses and cars cannot go through. Another interesting thing about bajaj is that passengers can bargain the fare to their destination. However, the routes for bajaj are now limited comparing to previous years and since the local government forbids bajaj to go through main boulevards. Moreover, a bajaj driver is one of the occupations for people with relatively lower educational background in comparison to employees working in offices in Jakarta. In 1970s, bajaj started to become a transportation mode in Jakarta known as having bright orange color, and making noise as well as pollution from waste gas. In early 2000s, the government of Jakarta decided to change the appearance of bajaj into 'bajaj BBG' with blue color to conform the image of a more environmentally friendly transportation since bajaj now uses gas as its fuel that produces less noise and waste gas.

The phenomena of bajaj 'ngetem' in Jakarta contributes to the traffic problems in Jakarta, although bajaj is actually only one of other factors contributed to the traffic problems. The problem arisen in relation to bajaj 'ngetem' is partly caused by the effort of local authorities who want to keep the city in order, especially from the physical appearance of the city. Occupying a part of the street for 'ngetem' is considered an inappropriate and disturbing, but unfortunately there is no significant effort from the authorities to find a solution to this inappropriateness in the city nor to provide space for bajaj to wait for the passengers. As a matter of fact, the authorities seldom try to understand the phenomena of 'ngetem' from bajaj drivers' perspective. Bajaj drivers need to find passengers and they understand that there is an opportunity from unintegrated transportation system in Jakarta. Bajaj and ojek (motorcycle) drivers are two alternatives to bring people to their destination especially before or after using bus or train. The pedestrian infrastructure in Jakarta does not encourage people to walk their last mile when commuting, and informal market occupies many of the walkways. This condition encourages people to use bajaj.

In fact, the phenomena of bajaj 'ngetem' also related to taxi and ojek drivers who want to find passengers, as well as other economic activities such as street vendors. There is also pressure from a group of people or a gang who claim a particular place in the city 'belongs' to them and if bajaj drivers want to stop for a while in that place they need to pay. In the end, bajaj 'ngetem' creates an interesting phenomenon in the city life and emphasize how space claiming and negotiation of space become an inseparable part of Jakarta urban life. In this respect, the chaotic forms as well as spontaneous practices of the city appear as autonomous systems of urban development.

Manggarai Station is located in Tebet, South of Jakarta that serves primarily as a commuter station for Jakarta and its surrounding areas. Since Jakarta has different kind of transportation systems to support the high mobility of its inhabitants, transit areas becomes very important. In this study, we consider Manggarai Station as one of important urban structures as well as the place where negotiated urban spaces happens. The activities at Manggarai Station also shows interactions among different subjects and how people use space including the possibility of claiming space to fulfill people's need. 


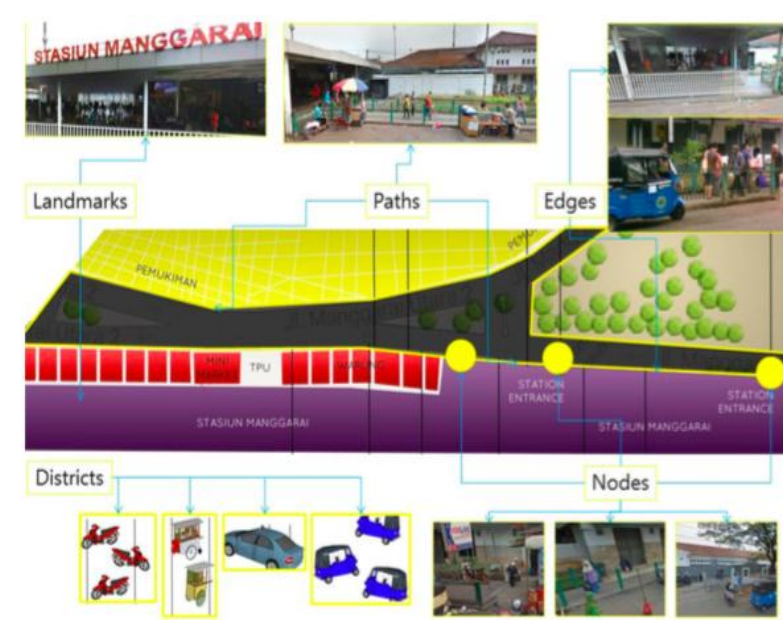

Fig. 1. Physical elements around Manggarai Station.

Figure 1 shows the five physical elements that create an image of the city according to Lynch's elements of the city. There are some paths such as sidewalks and paths for passengers and pedestrians around Manggarai Station that bring people to the station's entrances. Boundaries between buildings and the surrounding areas create edges, for instance between the Manggarai Station's building and the streets or fences around the stations. Manggarai Station has some districts, or areas with distinctive characters such as a big place and a fast movement. The Manggarai area is widely known as a transit area with a long station building and fences as part of the identifying character of the area. Nodes in the station can be understood as focal points and intersections near the main entrance and intersections of users and paths. The strategic location of Manggarai Station and the big station building creates a readily identifiable object which serve as external reference points. The entrance of Manggarai Station also can be understood as a landmark for its big signage and importance to the surrounding areas.
Bajaj 'ngetem' around Manggarai Station shows the existence of urban informality and negotiated spaces. Spaces that are created from the station building, some physical barriers, and streets can be seen as leftover spaces during certain time. Street vendors, bajaj-, taxi-, and ojek drivers occupy the leftover space and try to divide and negotiate space among themselves. Space division and communication among those drivers become important for their negotiation. Figure 2 describes the occupation of spaces at Manggarai Station as a result of 'ngetem' done by bajaj-, ojek-, and taxi drivers. The arrangement of 'ngetem' areas show that there are not only one group who need and claim informal spaces but also a negotiation between three different kinds of vehicles. The occupation and claiming of spaces also indicate the emergence of both individual and collective practices.

Bajaj drivers occupy strategic areas mostly near the entrance and crossings. The entrance of the station has one-meter-high fences to direct people to the entrances. As a solid element, those fences create a clear border of inside-outside for the station. From this situation, bajaj drivers can clearly observe passengers getting out of the station so that they can call passengers to use bajaj. The fences and the wide openings at the front façade of the station create noticeable solid-void elements that give an opportunity for bajaj drivers to mark their spot. Passengers, who during their transit at Manggarai station sometimes do various activities like shopping, are directed to the place of bajaj 'ngetem' through physical elements and recognize the presence of bajaj both from visual and auditory. There are some food vendors and small shops located outside the station and people can see the lines of bajaj 'ngetem' as people move through the entrances. Some areas outside passenger main areas may be called a leftover
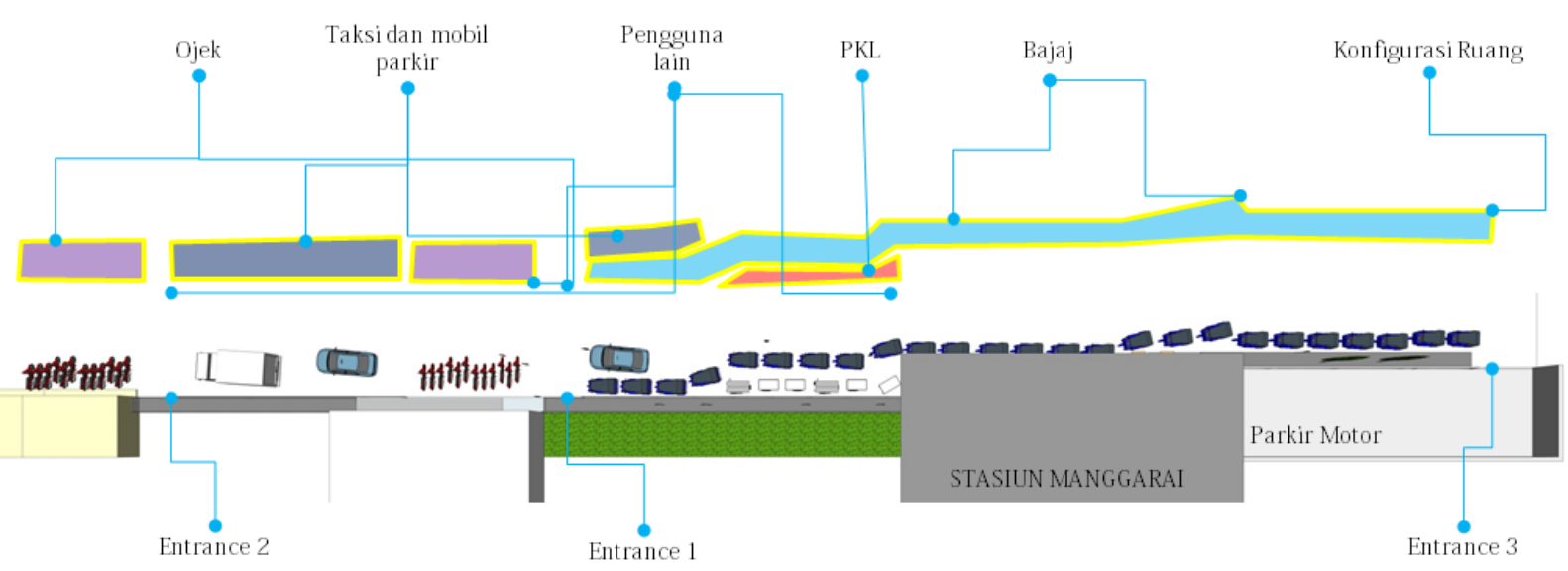

Fig. 2. Space arrangement at the main entrance of Manggarai Station. 
space - for instance near the side walk and some corners outside the station - because people seldom use those spaces or only stay for a short time. Bajaj drivers see the opportunity to use spaces in the outer part of the building as a leftover space and consider that space as necessary for their activities.

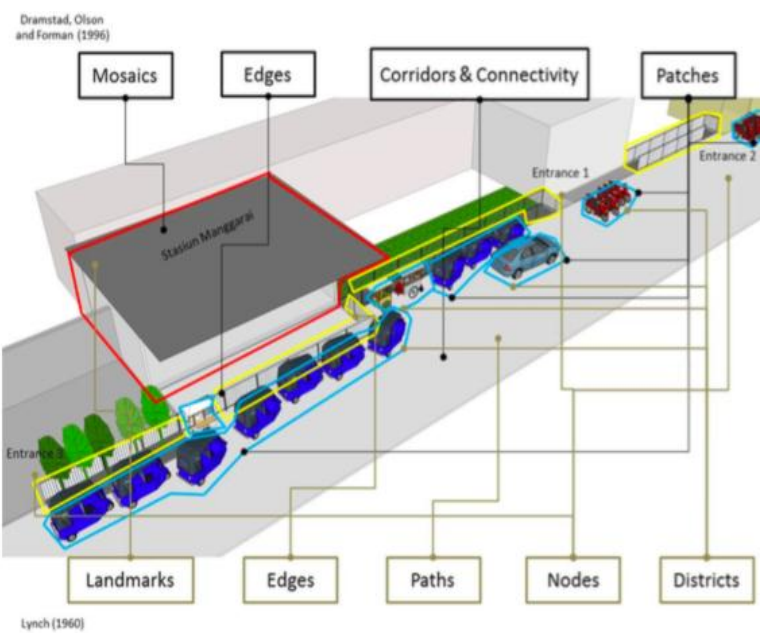

Fig. 3. Physical elements at Manggarai Station.

The elements like edges, barriers, corridors and connections can be understood through the station's structures and the surroundings. Fences, stairs, walls and canopies create edges and barriers that create borders of spaces as well as different spatial qualities in our lived experiences. Corridors and connections direct passenger such as through paths to every corner of the station. Connections among those elements highlight the importance of each element to support main activities of people in the station. Stepping stones elements come along with the interaction of corridors and connections that have important role as rest and pause areas for user before they move to next activity. At the same time, there are not many spaces that become continuous corridors and connections to support social and spatial interaction because paths, corridors and connections at Manggarai Stations are simply lead people to gates and streets. This tells us how stepping stones element in urban informality gives some advantages for people who occupy the leftover space around because many people will use or see the stepping stones and the surroundings. Bajaj drivers park their vehicles in strategic areas so that many people around the stepping stones can see them. Those drivers, who look beyond officially designed practices, appropriate the function of space and even recreate domestic arrangement and rule to support their needs. In short, there are some temporal and informal activities as well as spontaneity in those counter practices done by bajaj drivers.

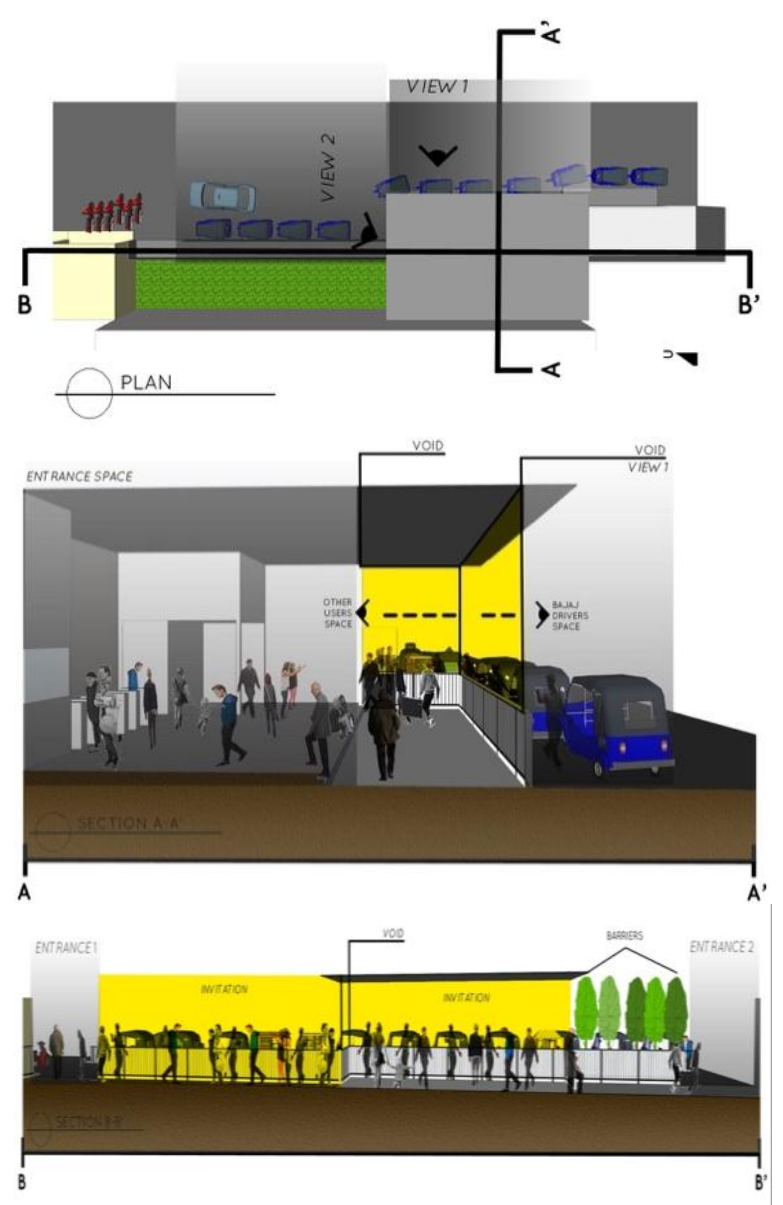

Fig. 4. Plan and sections of Manggarai Station that show solid-void elements.

The phenomena of bajaj 'ngetem' at Manggarai Station are both strategy and tactic done by bajaj drivers because those drivers look for opportunity in the informal or leftover space around the station. According to the idea of strategy and tactic, every bajaj that come to pangkalan must follow the order and wait for passenger in a row (Figure 5). When a passenger comes and takes the first bajaj (position 1 and 2), it makes other bajaj in the line (position 3-8) moves forward. From inside the station, passengers can actually see bajaj in position 3 and 4 clearly, but when they want to get in the vehicle, they are asked to move to bajaj in position 1 and 2. This rule makes more bajaj can stay in the line. Moreover, some food vendor may stay very close to position 3 and 4 and attract passengers to come closer. Bajaj that stay in position 1-4 are active in calling passengers while bajaj in position 5-8 are passive. What seems to chaotic is actually in order. The rule applied in 'ngetem' also affect other users such as ojek- or taxi drivers and street vendors to follow their own rule and to respect other people's rule in finding passengers or customers. 


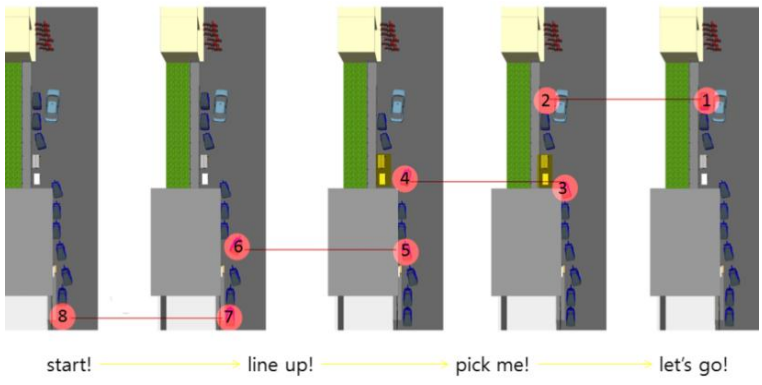

Fig. 5. Bajaj's order as strategy of occupying leftover space

Tactics are related to daily activities and affected by time. Figure 6 depicts how in different time, there will be different activities and various possibilities of using the leftover space around Manggarai Station. Around 7-10 A.M. during working days, many people are in a hurry to go to their works. This situation increases the opportunity for street vendors and bajaj drivers as dominant users of informal space around Manggarai Station claim the informal and leftover spaces for them. Street vendors offer food to go for people waiting for the transportation. Accordingly, bajaj drivers take the opportunity to offer alternative transportation with its ability to cut across the traffic and they openly call the passenger to get in their bajaj. During this time, it is possible for bajaj drivers to call the passenger even though they are not in the front row, because the probability to get a passenger is very good since there are so many people during the rush hours. As the time goes by, those hectic-morning-activities seems to become normal again and the leftover space is occupied with less bajaj drivers and those drivers have to wait for quite a long time to get a passenger. The rule of "whose bajaj waits in the front row will get a passenger' is strictly applied to 'ngetem'. In the afternoon, bajaj drivers around Manggarai Station start to claim the leftover space around four o'clock as people start to go back from their works. During the busiest time in the morning and in the late afternoon, bajaj drivers usually wait or 'ngetem' only for a short time and some street vendors and ojek drivers may also quickly take over their empty space.

As parts of urban economic and transportation system, bajaj deserves more attention in urban spaces not only to accommodate their activities but also to support the need a comprehensive transportation system. The discussion on bajaj 'ngetem' shows how urban informality at Manggarai Station changes through time that gives us a variation of urban space quality. Bajaj as one of Jakarta's transportation modes and actors in urban economy can foster the development of the city through self-organized forms and practices. Claiming space, spontaneity, conti- nuous change, and lack of fixed values are the way bajaj 'ngetem' negotiates space. With this negotiated space, borders of activities defined by physical elements also changes and thus strategy and tactic of bajaj drivers may affect borders and qualities of space at Manggarai Station. In relation to urban space, the application of the concept of urban informality in designing the urban space should integrate both informal with formal practices as well as accommodate the need for informal activities such as bajaj 'ngetem' because informal activities also play a role in shaping the image of the city that should not be considered as an excess to formal city structure.

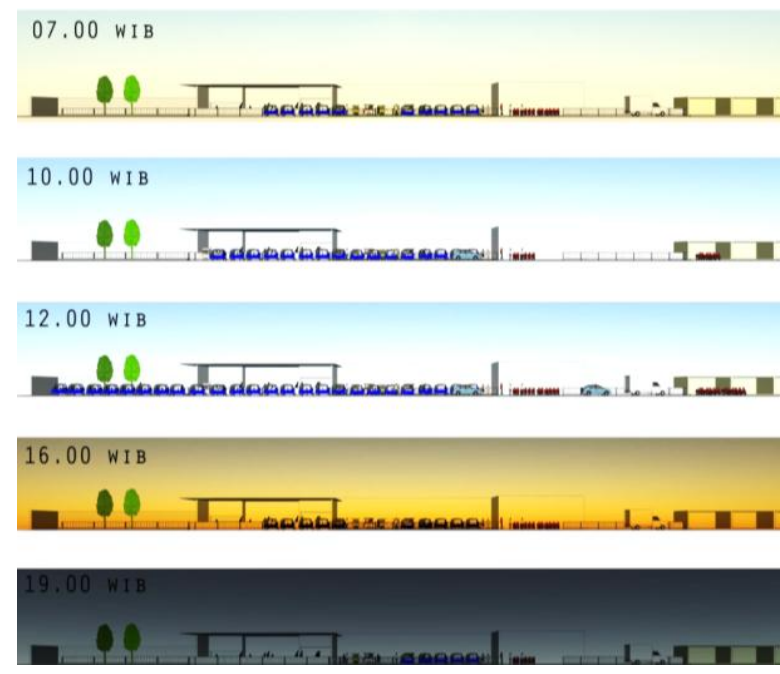

Fig. 6. The condition of pangkalan bajaj in different time

\section{CONCLUSION}

Based on the discussion on informal activities at Manggarai Station, bajaj drivers manage their business by occupying leftover urban space at the station. Elements of the city, even those usually seen as leftover space and considered bad for the city image, are actually a part of the mosaics of urban life. The physical elements of the Manggarai Station create some opportunities bajaj drivers to do some strategies and tactics in claiming and using the leftover space. The strategy that they use is related to the use of physical elements so that people know their existence in some strategic areas. The tactics that they use is related to continuous changes of spatial interaction in different times. Bajaj drivers do some interaction in leftover space, like marking the space by their lines up while 'ngetem'. With respect to the traditional methods of urban planning that usually focuses on order, this study concludes that informal dynamics of bajaj 'ngetem' proves to have a significant meaning in looking beyond officially designed practices. 
The idea of strategy and tactic in bajaj 'ngetem' can help us to understand the everyday life of the city, and how informal urban spaces are as important as formal and structured spaces. The place for bajaj 'ngetem', which is usually seen as an ugliness in urban areas, gives an opportunity to develop informality in Jakarta into something desirable and good structured. Considering informality in designing urban space can be an important element to improve quality of life and help to organize visual order in the urban environment rather than ignoring the existence those informalities.

By discussing the phenomena of bajaj 'ngetem', this study highlights the existence of informality in urban space and also a negotiation of space that occurs in informal and leftover spaces. The existence of everyday spaces is completing each other performance and the meaning of urban space are continually being redefined in the practice through lived experiences. Through the activity of 'ngetem', this study recognizes a multiplicity of simultaneous urban interactions, which are created by elements and subjects in urban spaces. In addition to this, discussing urban informalities such as bajaj 'ngetem' in informal urban space acknowledges the amazing reality of bajaj as offering an alternative of public transportation in the city and having an ability to respond to informal urban space. In short, both planner and users of the city have important role for using and developing the urban space, and it is important to incorporate the informal activities to appropriate the function of space and create opportunity in the everyday life of the city.

\section{ACKNOWLEDGMENT}

The authors thank Universitas Indonesia that provides part of the funds for the research, through PITTA program.

\section{REFERENCES}

Appadurai, A. (2000). Grassroots globalization and research imagination. Public Culture, 12(1), pp. $1-19$.

Borden, I., Kerr, J., Randall, J. \& Pivaro, A. (eds.) (2011). The Unknown City: Contesting Architecture and Social Space, Cambridge, London: MIT Press.

Crawford, M. (1999). Everyday Urbanism. New York: The Monacelli Press.

Davis, M. (2006). Planet of Slums. London: Verso.

De Certeau, M. (1984). Practice of Everyday Life, translated by Steven Rendall, Berkeley: University of California Press.
De Soto, H. (1989). The Other Path: the Invisible Revolution in the Third World. New York: Harpercollins.

Friedmann, J. (1987). Planning in the Public Domain: from Knowledge to Action. Princeton: Princeton University Press.

Hackenbroch, K. (2011). Urban Informality and Negotiated Space, The Planning Review, pp. 5969. Hill, J. (1988). Occupying Architecture: Between the Architects and the User. London: Routledge.

Jacobs, J. (1961). The Death and Life of Great American Cities. Toronto: Random House.

Kudva, N. (2009). The Everyday and the Episodic: The Spatial and Political Impacts of Urban Informality. Environment and Planning A, 41(7), pp.1614-1628.

Landry, C. (2006). The Art of City Making. London: Earthscan.

Lefebvre, H. (1991). The Production of Space. Cambridge: Blackwell.

Lynch, K. (1960). The Image of the City. Cambridge: The Technology Press \& Harvard University Press.

McFarlane, C. (2012). Rethinking Informality: Politics, Crisis, and the City. Plan Theory Practice, 13, pp. 89-108.

Mehrotra, R. (2008) Between Sanctioned and Shadow Order. In: Ruby I, Ruby A (eds) Urban Transformation. Berlin: Ruby Press.

Peraboni, C. (2010). Reti ecologiche e infrastrutture verdi, Milan: Maggioli Publisher.

Roy, A. \& Alsayyad, N. (eds) (2004). Urban Informality: Transnational Perspectives from the Middle East, Latin America, and South Asia. Lanham: Lexington Books.

Sassen, S. (2006). Territory, Authority, Rights: From Medieval to Global Assemblages. Princeton: Princeton University Press.

Saunders, W. (ed) (2008). Can Designers Improve Life in Non-Formal Cities? Harvard Design Magazine, 28.

Upton, D. (2002). Architecture of Everyday Life. New Literary History, 33(4), pp. 707-723.

Schneekloth, L. \& R. G. Shibley, R. (1995). Placemaking: The Art and Practice of Building Community, New York: Wiley.

Mochtar, M. \& Yasuo Hino. 2006. "Principal Issues to Improve the Urban Transport Problems in Jakarta. Osaka." Journal of Osaka City University, 47(2), pp.31-38. 
Nguyen-Hoang, Phuong, and Ryan Yeung. 2010. "What is Paratransit Worth?" Transportation Research Part A, 44, pp. 841-853.

Sudarmanto, B., Fujiwara, A. \& Zhang, J. (2013). "Does Paratransit Drivers' Low Job Satisfaction Lead to Job Mobility? Case Study of Taxi-like Paratransit Drivers in Jakarta City, Indonesia." Transport Research Board: 92nd Annual Meeting Compendium of Papers. Washington, DC: National Academy of Sciences.
Sumaedi, S., Bakti, I.G., Astrini, N., Rakhmawati, T., Widianti, T. \& Yarmen. M. (2014). Public Transport Passengers' Behavioural Intentions: Paratransit in Jabodetabek, Indonesia. Singapore: Springer.

Susilo, Y. O., Santosa, W., Joewono, T.B. \& Parikesit, D. (2007). "A Reflection of Motorization and Public Transport in Jakarta Metropolitan Area." IATSS Research, 31(1), pp. 59-68. 